\title{
136. An Enzyme Decomposing Common Antigenic Substance between Blood Group Substance and Diplococcus pneumoniae Type XIV. III
}

\author{
Chemical Effects of the Enzymes on Type XIV \\ Pneumococcal Polysaccharide \\ By Shigeru Yamamoto and Shoei Iseki \\ Department of Legal Medicine, School of Medicine, \\ Gunma University, Maebashi \\ (Comm. by Tanemoto Furuhata, M.J.A., Sept. 13, 1965)
}

Constituent sugars of Type XIV pneumococcal polysaccharide were revealed by Heidelberger et al..$^{1)}$ to be $N$-acetylglucosamine, glucose and galactose with molar ratio of $2: 1: 3$ according to Barker et al..$^{2)}$ and $1: 0.82: 1.7$ according to Distler and Roseman. ${ }^{3}$

Barker et al..$^{2}$ obtained from partial acid hydrolyzate of Type XIV pneumococcal polysaccharide two disaccharides, $4-O-\beta-\mathrm{D}-$ glucosyl2 -acetamido-2-deoxy-D-glucose and 3-O- $\beta$-(2-acetamido-2-deoxy)-Dglucosyl-D-galactose, in addition ${ }^{4)} 3-O-\beta-\mathrm{D}$-galactosyl-D-galactose, 3-O- $\beta$-D-glucosyl-D-galactose, $4-O-\beta-\mathrm{D}$-galactopyranosyl-D-glucose (lactose) and $O-\beta-\mathrm{D}$-galactosyl- $(1 \rightarrow 4)-O-\beta-\mathrm{D}$ - glucosyl $-(1 \rightarrow 4)-\mathrm{D}-(2-$ acetamido-2-deoxy)-glucose. They assumed that both $\mathrm{A}$ blood group substance and Type XIV pneumococcal polysaccharide held a common antigenicity due to the presence of $3-O-\beta-(2$-acetamido-2-deoxy)-Dglucosyl-D-galactose in their structures and also that $\mathrm{Le}^{\mathrm{a}}$ substance held an antigenicity common to Type XIV pneumococcal polysaccharide due to the presence of D-galactose in the non-reducing end.

Howe and his coworkers ${ }^{5}$ reported that cross-reactivity of blood group substance with anti-pneumococci Type XIV horse serum was abolished by enzymes from two strains of Clostridium tertium (Iseki and McClung 1259), and furthermore that antigenicity of Type XIV pneumococcal polysaccharide was reduced by both enzymes. Schiffman et al. ${ }^{6)}$ described $17 \%$ and $19 \%$, respectively, of galactose to be liberated from Type XIV pneumococcal polysaccharide as a result of action of the two kind of enzymes mentioned above. Recently, Barker et al., ${ }^{7}$ ) who analyzed structures of sugars released by a successive action of $\beta$-galactosidase, $\beta$-glucosidase, and $\beta$ glucosaminidase, induced in Klebsiella aerogenes N.C.I.B. 9479, clarified that first four units in Type XIV pneumococcal polysaccharide were $\beta$-D-Galp $1 \rightarrow 4 \quad \beta$-Gp $1 \rightarrow 4 \beta$-GpNAc $1 \rightarrow 3$ D-Galp and that thus obtained non-dialyzable substance which precipitated with anti- 
pneumococci Type XIV horse serum and which cross-reacted with human anti-B serum, contained 6-O-galactosyl 2-acetamido-2-deoxy $D$-glucose, consisting of $\alpha$-galactose and $\beta$-linked $N$-acetylglucosamine units.

Enzymes from $C l$. tertium $\mathrm{O}(\mathrm{H}), \mathrm{Le}^{\mathrm{a}}$ were indicated by Furukawa et $a l .^{8)}$ to destroy activity of blood group substance as well as an antigenicity common to human blood group substance in Type XIV pneumococcal polysaccharide and also it was elucidated by Yamamoto and Iseki $^{9}$ to release fucose, galactose and $N$-acetylglucosamine from human blood group substance.

This paper will describe chemical analysis of Type XIV pneumococcal polysaccharide digested by the enzyme preparation.

Materials and methods. 1. Polysaccharide. Type XIV pneumococcal polysaccharide was extracted from culture filtrates of Diplococcus pneumoniae DP-14 Clark and purified.

2. Antiserum. Anti-pneumococci Type XIV chicken serum was employed.

3. Enzyme. Enzyme preparation reported in the previous paper ${ }^{9)}$ was used.

4. Measurement of sugars. Protein-bound polysaccharide and hexose were measured by the methods described in the preceding paper $^{9)}$ and glucosamine, by Levy and McAllan's method. ${ }^{10)}$

After carrying out paper chromatography of the polysaccharide hydrolyzate (hydrolysis in $1 \mathrm{NH}_{2} \mathrm{SO}_{4}$ at $100^{\circ}$ for $8 \mathrm{hr}$.), glucose and galactose were separately determined by densitometer (Jouan). Degree of polymerization of sugar was determined according to the method of Peat et al..$^{11)}$

Experimental results. In order to detect the presence of nonreducing $\beta$-D-galactosyl residues and to remove it if possible, $\beta-D-$ galactosidase preparation fractionated from Bac. cereus $\mathrm{O}(\mathrm{H})$ was incubated with Type XIV pneumococcal polysaccharide at $\mathrm{pH} 6.8$ for 7 days at $37^{\circ}$. An antigenicity common to human blood group substance in it was unaffected and any sugar was scarcely liberated from it. These results indicate that there are not any $\beta$-D-galactosyl group attacked by the enzyme preparation or that Type XIV pneumococcal polysaccharide is unsuitable for a substrate of the enzyme preparation.

Fifty mg. of Type XIV pneumococcal polysaccharide (anthronetryptophan value) was incubated in the presence of fifteen $\mathrm{mg}$. of enzyme preparation from $\mathrm{Cl}$. tertium $\mathrm{O}(\mathrm{H}), \mathrm{Le}^{\mathrm{a}}$ in $20 \mathrm{ml}$. of $\mathrm{pH} 6.8$, $0.01 \mathrm{M}$ phosphate buffer at $37^{\circ}$ for $24 \mathrm{hr}$. After the incubation period, it was confirmed that the capacity to inhibit the agglutina- 
tion of human $\mathrm{O}$ red cells by anti-pneumococci Type XIV chicken serum was completely destroyed. Following dialysis of the incubation mixture, paper chromatography and high voltage electrophoresis ${ }^{12)}$ were carried out to separate and detect sugars present in the dialyzable portion. $N$-acetylglucosamine, glucose and galactose were shown on chromatograms, the first in a larger amount than the other two. Besides, small amounts of tri- to dodeca-saccharides, composed of three constituent sugars, were located on the chromatograms.

Table I. Change in sugars of Type XIV pneumococcal polysaccharide caused by enzyme treatment

\begin{tabular}{|c|c|c|c|}
\hline Enzyme treatment & Before & & \\
\hline Dialysis & & Non-dialyzate & Dialyzate \\
\hline $\begin{array}{l}\text { Anthrone-tryptophan value } \mathrm{mg} . \\
\text { (as glucose) }\end{array}$ & 50 & $\begin{array}{l}47.7 \\
95.3\end{array}$ & $\begin{array}{l}2.3 \\
4.7\end{array}$ \\
\hline $\begin{array}{l}\text { Hexose } \\
\qquad \text { (as glucose) }\end{array}$ & $\begin{array}{l}21.8 \\
121\end{array}$ & $\begin{array}{l}19.7 \\
90.3 \\
109\end{array}$ & $\begin{array}{c}2.1 \\
9.7 \\
12\end{array}$ \\
\hline $\begin{array}{r}\mathrm{mg} . \\
\% \\
\mu \text { moles }\end{array}$ & $\begin{array}{r}4.7 \\
26\end{array}$ & $\begin{array}{l}2.2 \\
45.8 \\
12\end{array}$ & $\begin{array}{r}2.5 \\
54.2 \\
14\end{array}$ \\
\hline
\end{tabular}

Quantitative analyses of sugars in the polysaccharide were made (see Table I). About $10 \%$ of hexoses and $54 \%$ of glucosamine were released from Type XIV pneumococcal polysaccharide by the action of the enzyme preparation from $C l$. tertium $\mathrm{O}(\mathrm{H}), \mathrm{Le}^{\mathrm{a}}$. The amount of hexoses was smaller than that of glucosamine. The molar ratio of hexoses to glucosamine was 12 to 14. As for the ratio of glucose to galactose, densitometrical analysis gave 2.3 to 1 in the nondigested polysaccharide, and 2 to 1 in the non-dialyzable portion from enzyme-digested polysaccharide. Accordingly, the molar ratio of $N$-acetylglucosamine: glucose: galactose in the used Type XIV pneumococcal polysaccharide was assumed to be about $1: 3.2: 1.4$. Comparing the ratio of glucose to galactose in the non-dialyzate with that in the non-treated polysaccharide, it was recognized that glucose was liberated in a larger amount than galactose.

Discussion. It has been known $^{13,14)}$ that Lacto- $N$-neotetraose was the strongest inhibitor of the cross-reaction of anti-pneumococci Type XIV horse serum with blood group substance, though $N$ acetyllactosamine was one of the inhibitor. Nevertheless, glucose as an constituent sugar of Lacto- $N$-neotetraose is absent in human 
blood group substance. Kabat ${ }^{14)}$ offered an opinion that the determinant sugar for the antigen common to Type XIV pneumococcal polysaccharide in human blood group substance was galactosyl- $\beta 1$, 4 - $N$-acetylglucosaminoyl- $\beta$ 1, 3-galactosyl residue, and also the determinant sugar for the antigen common to human blood group substance in Type XIV pneumococcal polysaccharide was galactosyl- $\beta$ 1 , 4-glucosyl- $\beta 1$, 3 -galactosyl residue. $O$ - $\beta$-D-galactopyranosyl-( $1 \rightarrow 4)$ $O$-( $N$-acetyl- $\beta$-D-glucosaminoyl)-( $1 \rightarrow 3)$-D-galactose was obtained by Rege $e t a l .{ }^{15)}$ from human blood group substances, but oligosaccharide of such a structure has not yet been obtained from Type XIV pneumococcal polysaccharide. ${ }^{2,4,7)}$

The evidence have been presented by authors' laboratory that Bac. cereus $\mathrm{O}(\mathrm{H})$ and Bac. cereus $\mathrm{Le}^{\mathrm{a}}$ enzymes had an ability to liberate fucose and galactose from $\mathrm{O}(\mathrm{H})$ or $\mathrm{Le}^{\mathrm{a}}$ substance without destroying the antigen common to Type XIV pneumococcal polysaccharide in them. From the present experimental results, including an failure of an $\beta$-D-galactosidase preparation from Bac. cereus $\mathrm{O}(\mathrm{H})$ to digest Type XIV pneumococcal polysaccharide, it would be presumed that $\beta$-D-galactopyranosyl- $\rightarrow 4-N$-acetyl-D-glucosamine might be an antigenic determinant of human blood group substance cross-reacting with anti-pneumococci Type XIV chicken serum or that the very $\beta$ - $N$-acetyl-D-glucosaminoyl- $1 \rightarrow 3$-D-galactose might be a preferable antigenic determinant of it. Barker et al. ${ }^{4)}$ conceived the latter to give a common antigenicity between A blood group substance and Type XIV pneumococcal polysaccharide. On the other hand, a determinant sugar for the antigen common to human blood group substance in Type XIV pneumococcal polysaccharide is presumed to be $\beta$ - $N$-acetyl-D-glucosaminoyl-1 $\rightarrow 3$-D-galactose.

Conclusion. 1. Enzymes from $\mathrm{Cl}$. tertium $\mathrm{O}(\mathrm{H}), \mathrm{Le}^{\mathrm{a}}$ release from Type XIV pneumococcal polysaccharide $N$-acetylglucosamine, glucose and galactose as simple sugars as well as small amounts of several oligosaccharides, composed of three constituent sugars, in the course of destruction of the antigen common to human blood group substance in it.

2. The determinant sugar for the antigen common to Type XIV pneumococcal polysaccharide in human blood group substance might presumably be $\beta$-D-galactosyl-1 $\rightarrow 4-N$-acetyl-D-glucosamine or $\beta$ - $N$ acetyl-D-glucosaminoyl-1 $\rightarrow 3$-D-galactose. The latter disaccharide might presumably have a role of the determinant sugar for the antigen common to human blood group substance in Type XIV pneumococcal polysaccharide. 


\section{References}

1) Heidelberger, M., Barker, S. A., and Stacey, M.: Components of the specific polysaccharides of type IX, XII, and XIV pneumococcus. Science, 120 (3124), 781-782 (1954).

2) Barker, S. A., Heidelberger, M., Stacey, M., and Tipper, D. J.: Immunopolysaccharides. Part X. The structure of the immunologically specific polysaccharide of Pneumococcus Type XIV. J. Chem. Soc., 3468-3474 (1958).

3) Distler, J., and Roseman, S.: Polysaccharide and glycolipid synthesis by cellfree preparation from Type XIV pneumococcus. Proc. Natl. Acad. Sci., 51(5), 897-905(1964).

4) Barker, S. A., Keith, M. C., and Stacey, M.: Monosaccharide sequence in Pneumococcus type XIV polysaccharide. Nature, 189(4766), 746-747 (1961).

5) Howe, C., Schiffman, G., Bezer, A. E., and Kabat, E. A.: Immunochemical studies on blood groups. XX. The effects of Clostridium tertium enzymes on blood group $\mathrm{A}, \mathrm{B}$, and $\mathrm{O}(\mathrm{H})$ substances and on type XIV pneumococcal polysaccharide. J. Amer. Chem. Soc., 80(24), 6656-6661 (1958).

6) Schiffman, G., Howe, C., and Kabat, E. A.: Immunochemical studies on blood groups. XXI. Chromatographic examination of constituents split from blood group $\mathrm{A}, \mathrm{B}$, and $\mathrm{O}(\mathrm{H})$ substances and from type XIV pneumococcal polysaccharide by Clostridium tertium enzymes. J. Amer. Chem. Soc., 80 (24), 6662-6670 (1958).

7) Barker, S. A., Pardoe, G. I., Stacey, M., and Hopton, J. W.: Degradation of type XIV Pneumococcus polysaccharide by induced enzymes. Nature, 204 (4962), 938-939 (1964).

8) Furukawa, K., Fujisawa, K., and Iseki, S.: An enzyme decomposing common antigenic substance between blood group substance and Diplococcus pneumoniae Type XIV. I. Serological action of the enzyme on blood group substances. Proc. Japan Acad., 38(7), 371-376 (1962).

9) Yamamoto, S., and Iseki, S.: An enzyme decomposing common antigenic substance between blood group substance and Diplococcus pneumoniae Type XIV. II. Chemical effects of the enzyme on water-soluble blood group substances. Proc. Japan Acad., 40(7), 593-598 (1964).

10) Levy, G. A., and McAllan, A.: The $N$-acetylation and estimation of hexosamines. Biochem. J., 73(1), 127-132 (1959).

11) Peat, S., Whelan, W. T., and Roberts, J. G.: Determination of the degree of polymerization of reducing oligosaccharides. J. Chem. Soc., 2258-2260 (1956).

12) Foster, A. B.: Ionophoresis of some disaccharides. J. Chem. Soc., 982-986 (1953).

13) Watkins, W. M., and Morgan W. T. J.: Further observations on the inhibition of blood-group specific serological reactions by simple sugars of known structure. Vox Sang., 7(2), 129-150 (1962).

14) Kabat, E. A.: Immunochemical studies on blood groups. XXIX. Action of various oligosaccharides from human milk in inhibiting the cross-reactions of Type XIV antipneumococcal sera with partially hydrolyzed blood group substances (Pl fractions). Arch. Biochem. Biophys., Suppl. 1, 181-186 (1962).

15) Rege, V. P., Painter, T. J., Watkins, W. M., and Morgan, W. T. J.: Three new trisaccharides obtained from human blood-group A, B, H, and Le substances. Possible sugar sequences in the carbohydrate chains. Nature, 200(4906), 532-534 (1963). 